\title{
GH treatment reduces trunkal adiposity in HIV-infected patients with lipodystrophy: a randomized placebo-controlled study
}

\author{
Livio Luzi, Elena Meneghini, Sabrina Oggionni ${ }^{1}$, Giuseppe Tambussi ${ }^{1}$, Lucia Piceni-Sereni $^{1}$ and Adriano Lazzarin ${ }^{1}$ \\ Departments of Internal Medicine and ${ }^{1}$ Division of Infectious Diseases, San Raffaele Scientific Institute, via Olgettina 60, 20132 Milan, Italy
}

(Correspondence should be addressed to L Luzi; Email: luzi.livio@hsrit)

\begin{abstract}
Objective: HIV lipodystrophy is a common complication of highly active anti-retroviral therapy, characterized by both metabolic and morphological features. The most feared morphological feature is body fat redistribution leading to HIV lipodystrophy. GH is known to induce reduction of visceral obesity and body fat redistribution in adults.

Design: A crossover, double-blind protocol of $\mathrm{GH}$ treatment (6 months of recombinant human $\mathrm{GH}(\mathrm{rhGH})$ at $0.2 \mathrm{IU} / \mathrm{kg}$ per week) vs placebo (6 months of placebo with a 2 month wash-out between periods) was performed.

Subjects and setting: Thirty HIV-infected patients with lipodystrophy were recruited in the Outpatient Clinic of the Division of Infectious Diseases of San Raffaele Scientific Institute in Milan, Italy.

Main outcome and results: Our data demonstrate an effect of low-dose rhGH administration in reducing trunk adiposity in HIV patients with lipodystrophy ( $\Delta$ from basal: $-394 \pm 814 \mathrm{~g}, P=0.048$ with respect to placebo. Data are given as mean \pm standard deviation). A trend to an increase of arm depots was also shown ( $\Delta$ from basal: $+43 \pm 384 \mathrm{~g}, P=\mathrm{NS}$ with respect to placebo). Interestingly, no detrimental metabolic effects on glucose tolerance and lipid levels were found following the administration of $0.2 \mathrm{IU} / \mathrm{kg}$ per week of rhGH for 6 months.

Conclusions: Low-dose GH administration is an effective treatment in reducing trunk obesity in HIVinfected patients with lipodystrophy.
\end{abstract}

European Journal of Endocrinology 153 781-789

\section{Introduction}

The advent of highly active anti-retroviral treatment (HAART) caused a dramatic improvement of patient survival in HIV-related infection (1). Since the introduction of either protease inhibitors (PIs) or nucleoside and non-nucleoside reverse transcriptase inhibitors (NRTIs and NNRTIs respectively) in the therapy of AIDS, it was evident that these drugs were not devoid of important metabolic and morphological side-effects (2). Increases in blood lipid level (mainly triglycerides), uric acid concentration and glycemia were all reported with different incidences in populations of HIV-infected patients treated with PIs, NRTIs, NNRTIs or a combination of them (3-6). Along with metabolic alterations, many patients also show morphological changes in the distribution of body fat, with an increase in trunk adiposity and a reduction (or atrophy) of fat tissue in arms and legs being the most common form of lipodystrophy (2-6).

The common denominator of metabolic and morphological alterations of HIV-related lipodystrophy is insulin resistance, namely a reduction of the ability of insulin to increase glucose uptake and metabolism (1-6). Three mechanisms for both PIs $(2,3,5)$ or NRTIs $(3,6,7)$ have been proposed to justify the manifestation of lipodystrophy: (i) the inhibition of the peroxisome proliferator-activated receptor- $\gamma$ shown by PI (2); (ii) the resulting hypertriglyceridemia inducing insulin resistance by an indirect mechanism; and (iii) mitochondrial toxicity with inhibition of respiratory chain enzymes by NRTIs $(6,7)$. Interestingly, a number of hormone alterations have been described in HIV-infected patients: increased levels of fasting and post-prandial insulin and C-peptide concentrations (5), disrupted circadian rhythm of cortisol levels (with sporadic increased daily cortisoluria) (8), and, finally, a defect of growth hormone $(\mathrm{GH})$ secretion following a combined arginine/GH-releasing hormone (GHRH) stimulus $(9,10)$. In adulthood there is evidence that a defective $\mathrm{GH}$ secretion is associated with abnormal fat distribution (11) and that GH administration normalizes the pattern of fat deposition. Therefore, a crossover, double-blind protocol of GH treatment (6 months 
of $\mathrm{GH}$ at $0.2 \mathrm{IU} / \mathrm{kg} /$ week) vs placebo (with a 2 month wash-out between the two treatment periods) was performed. The aim of the study was to test whether $\mathrm{GH}$ administration is effective in reducing trunk obesity in HIV patients with lipodystrophy.

\section{Methods}

\section{Population}

The present protocol was evaluated and approved by the Institutional Ethical Committee of San Raffaele Scientific Institute. Written informed consent was obtained from all patients before entering the study protocol.

Thirty HIV-infected patients with lipodystrophy (with both the adipose tissue redistribution and the metabolic changes of the syndrome) were enrolled in this study. All patients were in a stable clinical condition and on the same anti-retroviral treatment for at least 3 months prior to their enrollment in the study. All patients were taking PIs along with NRTIs or NNRTIs. Patients with a body mass index (BMI) $>32 \mathrm{~kg} / \mathrm{m}^{2}$, diabetes mellitus, epilepsy, $\mathrm{CD}_{4}$ count $<200$ cells $/ \mathrm{ml}^{3}$,
Kaposi sarcoma or other major lung, heart, liver and nervous system disease were excluded from the present study. Table 1 shows the main biochemical and clinical data of study subjects. Table 5 contains the main metabolic parameter characteristics of lipodystrophy. Only 23 patients (out of 30 initially enrolled) completed the study.

\section{Study protocol}

Twenty-three patients completed the study. After being enrolled in the study patients were randomized either to Arm A (recombinant human GH (rhGH) first, then placebo) or to Arm B (placebo first, then rhGH). The first treatment was continued for 6 months. The second treatment was also given for 6 months after a 2 month interruption to allow pharmacological wash-out. The entire protocol lasted 14 months. The dose of rhGH (Genotropin, Pfizer) was given daily s.c. $(0.028 \mathrm{IU} / \mathrm{kg}$ per day corresponding to $0.2 \mathrm{IU} / \mathrm{kg}$ per week).

Anthropometrics, dual-energy X-ray absorptiometry (DXA), oral glucose tolerance tests (OGTTs) and GH secretion by GHRH plus arginine tests were performed four times: (i) at the beginning of the study; (ii) at the

Table 1 Demographic and anthropometric characteristics of the study groups. Data are given as mean \pm standard deviation (S.D.).

\begin{tabular}{|c|c|c|c|}
\hline & ALL & Arm A (sequence Genotropin/placebo) & Arm B (sequence placebo/Genotropin) \\
\hline \multicolumn{4}{|l|}{ PERIOD 1} \\
\hline \multicolumn{4}{|l|}{ BASAL } \\
\hline Patients $(n)$ & 30 & 15 & 15 \\
\hline Sex ratio $(M / F)$ & $13 / 17$ & $5 / 10$ & $8 / 7$ \\
\hline Age (years) & $39.63 \pm 8.54$ & $38.07 \pm 8.48$ & $41.20 \pm 8.59$ \\
\hline Weight (kg) & $64.50 \pm 10.75$ & $61.47 \pm 10.59$ & $67.53 \pm 10.38$ \\
\hline $\mathrm{BMI}\left(\mathrm{kg} / \mathrm{m}^{2}\right)$ & $22.36 \pm 2.45$ & $21.61 \pm 2.41$ & $23.12 \pm 2.29$ \\
\hline \multicolumn{4}{|l|}{ END } \\
\hline Patients $(n)$ & 25 & 13 & 12 \\
\hline Sex ratio $(M / F)$ & $10 / 15$ & $4 / 9$ & $6 / 6$ \\
\hline Weight (kg) & $64.42 \pm 11.74$ & $61.12 \pm 11.64$ & $68.00 \pm 11.23$ \\
\hline$\Delta \mathrm{WEKIGHT}^{\prime}$ & - & $+0.04 \pm 1.59$ & $-0.75 \pm 2.83$ \\
\hline$\Delta$ Waist & $-0.57 \pm 3.54$ & $+0.62 \pm 3.71$ & $-2.1 \pm 3.54$ \\
\hline$\Delta \mathrm{Hip}$ & $-1.11 \pm 2.48$ & $-0.38 \pm 2.18$ & $-2.05 \pm 2.63$ \\
\hline$\Delta$ Trunk & $-1.00 \pm 3.11$ & $-1.38 \pm 2.9$ & $-0.50 \pm 3.45$ \\
\hline$\Delta$ Thigh & $+1.07 \pm 2.51$ & $+0.77 \pm 2.83$ & $+1.45 \pm 2.11$ \\
\hline$\Delta$ Biceps & $+0.10 \pm 2.39$ & $-0.77 \pm 2.58$ & $+1.22 \pm 1.63$ \\
\hline$\Delta$ Triceps & $+0.40 \pm 3.06$ & $+0.13 \pm 3.91$ & $+0.76 \pm 1.5$ \\
\hline \multicolumn{4}{|l|}{ PERIOD 2} \\
\hline \multicolumn{4}{|l|}{ BASAL } \\
\hline Patients $(n)$ & 23 & 11 & 12 \\
\hline Sex ratio $(M / F)$ & $9 / 14$ & $3 / 8$ & $6 / 6$ \\
\hline Weight (kg) & $64.09 \pm 10.69$ & $59.36 \pm 8.46$ & $68.42 \pm 10.97$ \\
\hline \multicolumn{4}{|l|}{ END } \\
\hline Patients $(n)$ & 20 & 10 & 10 \\
\hline Sex ratio $(M / F)$ & $9 / 11$ & $3 / 7$ & $6 / 4$ \\
\hline Weight $(\mathrm{kg})$ & $65.15 \pm 11.82$ & $61.71 \pm 11.29$ & $68.58 \pm 11.88$ \\
\hline$\Delta$ WËIGHT & - & $+1.71 \pm 3.75$ & $-0.62 \pm 3.34$ \\
\hline$\Delta$ Waist & $+0.39 \pm 4.68$ & $+3.05 \pm 5.19$ & $-1.83 \pm 2.82$ \\
\hline$\Delta$ Hip & $-0.07 \pm 7.00$ & $-1.95 \pm 7.18$ & $+1.50 \pm 6.74$ \\
\hline$\Delta$ Trunk & $-0.07 \pm 4.40$ & $+1.75 \pm 4.10$ & $+1.50 \pm 6.74$ \\
\hline$\Delta$ Thigh & $+1.25 \pm 2.55$ & $+1.20 \pm 1.87$ & $+1.29 \pm 3.09$ \\
\hline$\Delta$ Biceps & $-0.05 \pm 1.32$ & $+0.22 \pm 1.18$ & $-0.28 \pm 1.44$ \\
\hline$\Delta$ Triceps & $-0.82 \pm 2.98$ & $-0.78 \pm 3.69$ & $-0.86 \pm 2.40$ \\
\hline
\end{tabular}

www.eje-online.org 
conclusion of 6 months of Genotropin (rhGH)/placebo or placebo/Genotropin; (iii) after 2 months of washout period; and (iv) at the conclusion of 6 months of Genotropin/placebo or placebo/Genotropin.

\section{Anthropometrics}

Weight, height and waist/hip ratio were recorded four times during the experimental protocol.

\section{Body composition}

DXA was performed four times during the experimental protocol.

\section{OGTT}

A $75 \mathrm{~g}$ OGTT was performed in all patients four times during the experimental protocol. The 1997 American Diabetes Association criteria were used to classify patients into; diabetics, those having impaired glucose tolerance or normal, based on basal, 1st hour and 2nd hour glycemia (12).

\section{GH secretion}

Combined GHRH $(50 \mu \mathrm{g})$ and arginine hydrochloride (15 g) infusions were performed four times: (i) at the beginning of the study; (ii) at the conclusion of 6 months of Genotropin/placebo or placebo/Genotropin; (iii) after 2 months of wash-out period; and (iv) at the conclusion of 6 months of Genotropin/placebo or placebo/Genotropin.

\section{Analytical determinations}

All analytical determinations were performed in the core laboratory of San Raffaele Scientific Institute. Blood cells count, $\mathrm{CD}_{4}$ count, virus concentration, alanine aminotransferase and aspartate aminotransferase, free triiodothyronine and free thyroxine, thyrotropin, plasma glucose, total cholesterol, low-density lipoprotein (LDL), high-density lipoprotein (HDL), triglycerides and uric acid were measured by standard techniques as previously described (13). Glycosylated hemoglobin (HbA1c) was measured by HPLC as previously described (13). Plasma insulin, C-peptide, GH, insulinlike growth factor-I (IGF-I) and tumor necrosis factor$\alpha$ (TNF- $\alpha)$ were measured by RIA as previously described (13).

\section{Statistical analysis}

For the recorded variables, descriptive statistics have been calculated. In particular, the mean, S.D., minimum and maximum with the median, if the case, for the quantitative variables and absolute and relative frequencies for the qualitative ones. The statistical analysis was by means of ANOVA, according to the two-period and two-treatment crossover design.

\section{Results}

Patients were randomly assigned to the two different therapeutic sequences (Arm A: 6 months of rhGH/ placebo, 2 months of wash-out; Arm B: 6 months of placebo/rhGH) and were homogeneous for age, sex distribution, body weight and BMI. Only 23 (73\%) patients started the second treatment period and only $20(67 \%)$ performed all the planned tests. Drop-outs were due to pregnancy (one case), hepatitis A (one case) and withdrawal of consent (two cases) during rhGH treatment, and increase of transaminase levels (one case), wrong randomization (one case) and withdrawal of consent (one case) during the placebo period.

The effects on body composition are presented in Table 2. Data are given as mean \pm standard deviation (S.D.). Independently from the sequence of the treatment (Arm A or Arm B) the total tissue percentage fat did not change significantly. Arm tissue percentage fat increased by $0.47 \pm 3.84 \%$ during rhGH treatment and decreased by $1.26 \pm 2.81 \%$ during placebo (Table 2). Leg tissue percentage fat decreased during rhGH (Arm A: $-0.68 \pm 2.05$; Arm B: $-0.67 \pm 1.67$, $P=0.0248)$ without any modification of lean tissue $(-16.2 \pm 739$ vs $-22.3 \pm 671, P=$ NS). Trunk tissue fat mass also decreased clearly in patients on rhGH $(-394.1 \pm 814.3 \mathrm{~g}), \quad P=0.0483$ with respect to placebo $(-16 \pm 1555)$. This effect was not coupled to an evident increase in lean tissue (trunk lean g: rhGH $+480.5 \pm 1398$; placebo $+679.9 \pm 1105)$. The data on the measurement of waist/hip ratio confirmed a decrease of the ratio in patients of Arm A, while no change was shown in patients of Arm B. No statistically significant differences were noted when results were analyzed by sex (data not shown).

Table 3 reports the results of the $75 \mathrm{~g}$ OGTT performed at the beginning and at the end of every treatment period. The data of the area under the curve for glucose (AUC 0-120 min) are corrected by subtraction of the basal glucose level. rhGH did not induce a statistically significant decrease of glucose AUC vs placebo. Plasma insulin and C-peptide levels were higher in the two basal periods with respect to the normal range of our laboratory, and did not vary after rhGH treatment. The homeostasis model assessment of insulin resistance (HOMA IR) index (calculated according to Matthews et al. (14)) did not change following rhGH treatment. In Table 3 are reported the total numbers of patients showing abnormal values of glycemia, HbA1c and fructosamine during rhGH and placebo administration (no difference between rhGH and placebo).

In Table 4 are summarized the results of the maximal GH stimulation test performed by combined infusion of GHRH $(50 \mu \mathrm{g})$ and arginine hydrochloride $(15 \mathrm{~g})$. 
Table 2 The effect of treatment on body composition ( $\Delta$ from basal). Data are given as mean \pm S.D.

\begin{tabular}{|c|c|c|c|c|c|c|}
\hline & $\begin{array}{l}\text { ALL Genotropin } \\
\text { (22 patients) }\end{array}$ & $\begin{array}{l}\text { ALL placebo } \\
\text { (21 patients) }\end{array}$ & $\begin{array}{c}\text { Arm A (sequence } \\
\text { Genotropin/placebo) } \\
\text { (Period 1) }\end{array}$ & $\begin{array}{c}\text { Arm A (sequence } \\
\text { placebo/Genotropin) } \\
\text { (Period } 2)\end{array}$ & $\begin{array}{c}\text { Arm B (sequence } \\
\text { Genotropin/placebo) } \\
\text { (Period 1) }\end{array}$ & $\begin{array}{c}\text { Arm B (sequence } \\
\text { placebo/Genotropin) } \\
\text { (Period 2) }\end{array}$ \\
\hline $\begin{array}{l}\text { Arm tissue } \\
\text { lean }(\mathrm{g})\end{array}$ & $-47.9227 \pm 473.799$ & $-171.895 \pm 796.383$ & $-6.391 \pm 445.319$ & $-30.155 \pm 239.228$ & $-278.200 \pm 1040.550$ & $-96.230 \pm 525.861$ \\
\hline $\begin{array}{l}\text { Arm tissue } \\
\text { fat }(g)\end{array}$ & $+43.885 \pm 384.339$ & $-97.933 \pm 227.480$ & $+26.033 \pm 487.373$ & $-114.455 \pm 210.430$ & $-85.541 \pm 239.584$ & $+65.240 \pm 231.133$ \\
\hline $\begin{array}{l}\text { Arm tissue } \\
\text { (\% fat) }\end{array}$ & $+0.47 \pm 3.84$ & $-1.26 \pm 2.81$ & $+0.547 \pm 4.658$ & $-1.738 \pm 3.835$ & $-0.909 \pm 1.822$ & $-0.375 \pm 2.791$ \\
\hline $\begin{array}{l}\text { Leg tissue } \\
\text { lean }(\mathrm{g})\end{array}$ & $+16.264 \pm 739.915$ & $+22.314 \pm 671.569$ & $-248.191 \pm 764.770$ & $+84.644 \pm 721.433$ & $-24.433 \pm 660.248$ & $+333.610 \pm 625.060$ \\
\hline $\begin{array}{l}\text { Leg tissue } \\
\text { fat }(\mathrm{g})\end{array}$ & $-69.841 \pm 315.670$ & $-73.619 \pm 408.133$ & $-136.100 \pm 389.271$ & $+88.422 \pm 237.349$ & $-195.150 \pm 473.596$ & $+9.670 \pm 185.547$ \\
\hline $\begin{array}{l}\text { Leg tissue } \\
\text { (\% fat) }\end{array}$ & $-0.394 \pm 1.594$ & $-0.221 \pm 1.451$ & $-0.676 \pm 2.046$ & $-0.383 \pm 0.845$ & $-0.674 \pm 1.669$ & $-0.055 \pm 0.753$ \\
\hline $\begin{array}{l}\text { Trunk tissue } \\
\text { lean }(\mathrm{g})\end{array}$ & $+480.423 \pm 1398.18$ & $+679.914 \pm 1105.33$ & $+219.391 \pm 955.280$ & $+912.344 \pm 1370.26$ & $+505.591 \pm 882.318$ & $+793.880 \pm 1802.77$ \\
\hline $\begin{array}{l}\text { Trunk tissue } \\
\text { fat }(\mathrm{g})\end{array}$ & $-394.1 \pm 814.3$ & $-16.4 \pm 1455.7$ & $-236.866 \pm 738.435$ & $+770.355 \pm 829.910$ & $-606.491 \pm 1570.27$ & $-582.780 \pm 899.056$ \\
\hline $\begin{array}{l}\text { Trunk tissue } \\
\text { (\% fat) }\end{array}$ & $-0.993 \pm 1.905$ & $-0.925 \pm 3.277$ & $-0.754 \pm 2.151$ & $+0.788 \pm 2.249$ & $-2.210 \pm 3.412$ & $-1.280 \pm 1.626$ \\
\hline $\begin{array}{l}\text { Total tissue } \\
\text { lean }(\%)\end{array}$ & $+552.600 \pm 1722.48$ & $+667.805 \pm 1591.62$ & $+114.358 \pm 1438.65$ & $+991.221 \pm 1941.24$ & $+425.250 \pm 1309.78$ & $+1078.49 \pm 1957.00$ \\
\hline $\begin{array}{l}\text { Total tissue } \\
\text { fat }(\mathrm{g})\end{array}$ & $-330.077 \pm 1152.25$ & $-221.052 \pm 1731.05$ & $-238.400 \pm 1214.40$ & $+761.911 \pm 1112.51$ & $-958.275 \pm 1778.95$ & $-440.090 \pm 1127.28$ \\
\hline $\begin{array}{l}\text { Total tissue } \\
(\% \text { fat })\end{array}$ & $-0.544 \pm 1.554$ & $-0.467 \pm 2.080$ & $-0.439 \pm 1.756$ & $0.544 \pm 1.561$ & $-1.225 \pm 2.150$ & $-0.670 \pm 1.352$ \\
\hline
\end{tabular}


Table $4 \mathrm{GH}(\mathrm{ng} / \mathrm{ml})$ peak secretion after GHRH and arginine infusion and plasma IGF-I (ng/ml) values. Data are given as mean \pm S.D.

\begin{tabular}{|c|c|c|c|c|c|c|}
\hline & $\begin{array}{l}\text { Arm A (sequence } \\
\text { Genotropin/placebo) }\end{array}$ & $\begin{array}{l}\text { Arm B (sequence } \\
\text { placebo/Genotropin) }\end{array}$ & $\begin{array}{c}\text { Arm A (sequence } \\
\text { Genotropin/placebo; males) }\end{array}$ & $\begin{array}{l}\text { Arm A (sequence } \\
\text { Genotropin/placebo; } \\
\text { females) }\end{array}$ & $\begin{array}{c}\text { Arm B (sequence } \\
\text { placebo/Genotropin; males) }\end{array}$ & $\begin{array}{c}\text { Arm B (sequence } \\
\text { placebo/Genotropin; } \\
\text { females) }\end{array}$ \\
\hline \multicolumn{7}{|l|}{ PERIOD 1} \\
\hline Patients $(n)$ & 15 & 15 & 5 & 10 & 8 & 7 \\
\hline $\mathrm{GH}$ & $31.41 \pm 28.57$ & $24.24 \pm 16.35$ & $15.12 \pm 6.74$ & $39.56 \pm 32.07$ & $24.29 \pm 17.70$ & $24.19 \pm 16.06$ \\
\hline IGF-I & $178.41 \pm 49.47$ & $160.73 \pm 50.15$ & $165.14 \pm 33.87$ & $185.05 \pm 56.12$ & $166.49 \pm 51.52$ & $154.14 \pm 51.73$ \\
\hline \multicolumn{7}{|l|}{ END } \\
\hline Patients $(n)$ & 12 & 12 & 4 & 8 & 6 & 6 \\
\hline GH & $36.81 \pm 37.38$ & $19.55 \pm 12.26$ & $11.78 \pm 4.76$ & $49.33 \pm 40.61$ & $17.62 \pm 11.59$ & $21.48 \pm 13.68$ \\
\hline IGF-I & $227.81 \pm 96.66$ & $146.58 \pm 43.09$ & $267.45 \pm 100.92$ & $207.99 \pm 94.71$ & $139.52 \pm 42.69$ & $153.63 \pm 46.29$ \\
\hline \multicolumn{7}{|l|}{ PERIOD 2} \\
\hline BASAL & 11 & 12 & 3 & 8 & 6 & 6 \\
\hline Patients $(n)$ & $29.48 \pm 18.22$ & $21.89 \pm 16.39$ & $20.13 \pm 14.67$ & $32.99 \pm 19.01$ & $15.40 \pm 13.07$ & $28.38 \pm 17.86$ \\
\hline $\mathrm{GH}$ & $206.44 \pm 82.61$ & $163.33 \pm 59.00$ & $231.90 \pm 90.90$ & $196.89 \pm 83.71$ & $155.40 \pm 74.01$ & $171.25 \pm 45.04$ \\
\hline IGF-I & & & & & & \\
\hline \multicolumn{7}{|l|}{ END } \\
\hline Patients $(n)$ & 10 & 9 & 3 & 7 & 5 & 4 \\
\hline $\mathrm{GH}$ & $30.32 \pm 29.51$ & $13.06 \pm 12.53$ & $9.70 \pm 10.60$ & $39.16 \pm 31.07$ & $13.80 \pm 14.41$ & $12.13 \pm 11.83$ \\
\hline IGF-I & $229.16 \pm 83.54$ & $187.66 \pm 94.96$ & $255.27 \pm 92.02$ & $216.10 \pm 84.66$ & $184.25 \pm 84.18$ & $191.76 \pm 116.82$ \\
\hline
\end{tabular}

GH peak secretion; $P=$ NS between treatments.

IGF-I; $P=$ NS between periods, $P=0.020$ between treatments. 
Table 5 Plasma lipids (mg/dl). Data are given as mean \pm S.D.

\begin{tabular}{lcc}
\hline & Arm A (sequence Genotropin/placebo) & Arm B (sequence placebo/Genotropin) \\
\hline PERIOD 1 & & $216.9 \pm 55.9$ \\
BASAL & $213.7 \pm 25.3$ & $39.5 \pm 10.7$ \\
Cholesterol (total) & $49.1 \pm 17.8$ & $126.5 \pm 45.4$ \\
HDL & $122.9 \pm 22.3$ & $254.3 \pm 118.9$ \\
LDL & $223.4 \pm 156.7$ & $238.3 \pm 92.0$ \\
Triglyceride & & $38.5 \pm 11.6$ \\
END & $205.6 \pm 25.3$ & $136.6 \pm 39.4$ \\
Cholesterol (total) & $44.8 \pm 12.2$ & $316.2 \pm 512.4$ \\
HDL & $124.4 \pm 23.3$ & \\
LDL & $184.8 \pm 92.6$ & $211.1 \pm 35.8$ \\
Triglyceride & & $39.0 \pm 12.8$ \\
PERIOD 2 & $215.6 \pm 40.1$ & $127.1 \pm 34.2$ \\
BASAL & $51.9 \pm 13.5$ & $227.4 \pm 83.9$ \\
Cholesterol (total) & $133.9 \pm 40.5$ & $202.2 \pm 42.9$ \\
HDL & $190.5 \pm 147.7$ & $34.3 \pm 8.6$ \\
LDL & & $135.4 \pm 35.4$ \\
Triglyceride & $242.3 \pm 61.5$ & $208.8 \pm 88.6$ \\
END & $48.0 \pm 17.1$ &
\end{tabular}

$P=0.05$ comparing the effect of Genotropin and placebo on total cholesterol and triglycerides.

mass, especially visceral fat mass, and in maintaining lean body mass. Reduction of the visceral fat following GH administration has a pivotal role in the positive modulation of insulin sensitivity (24).

Alterations of body composition, common in HIV infections, are increasingly reported after HAART, creating the new syndrome of HIV lipodystrophy. Investigations intended to clarify the dynamics of these alterations have pointed to an impaired GH secretion and GH pulse amplitude. As in obesity, visceral fat is the best predictor of reduced GH concentrations (25-28).

Successful treatment with recombinant GH at different doses has already been reported. The main positive outcome was a reduction in visceral adipose tissue. Subcutaneous adipose tissue also decreased, but proportionally less, and skeletal muscle mass increased (29-31). A relationship between the dose of GH administered and therapeutic effects was shown. The dose of rhGH employed in this study, even if lower than the dose previously used in HIV-infected patients, is still quite high, being indeed situated in the high range of GH replacement therapy for adult GH deficiency (32, 33). Low-dose GH administration $(0.07-0.10 \mathrm{IU} / \mathrm{kg}$ body weight) was proved effective in increasing lipolysis (by approximately 25\%) in 1 week, without affecting glucose and protein kinetics and without altering insulin sensitivity (23). Therefore, in our trial we chose to administer a very low dose of GH $(0.028 \mathrm{IU} / \mathrm{kg}$ body weight), low enough to minimize adverse effects but still efficient in inducing morphological changes in HIV adults. In fact, HIV patients are certainly more complicated than 'simply obese' men and their lipodystrophy may be more 'resistant' to the lypolytic action of GH. It is noteworthy that the effect on body composition was achieved at a dose devoid of detrimental metabolic and hormonal side-effects.

We analyzed the two groups of patients all together (22 patients on GH treatment, 21 patients on placebo) and summarize the results of body composition in Table 2. The data of body composition, obtained by DXA scan, show that rhGH induced a selective decrease of trunk tissue fat. There is also evident a change in composition of leg tissues with a decrease in percentage fat (rhGH -0.394 \pm 1.594 ; placebo $-0.221 \pm 1.451$ ). Overall the effect on body composition is almost exclusively on trunk tissue fat mass, without any statistically significant effect on leg and arm fat depots. We speculate that increasing the dose of GH injected or/and the length of GH treatment may also induce an effect on limbs (Fig. 1).

The low-dose GH replacement was sufficient to determine the effect on body fat distribution, without causing

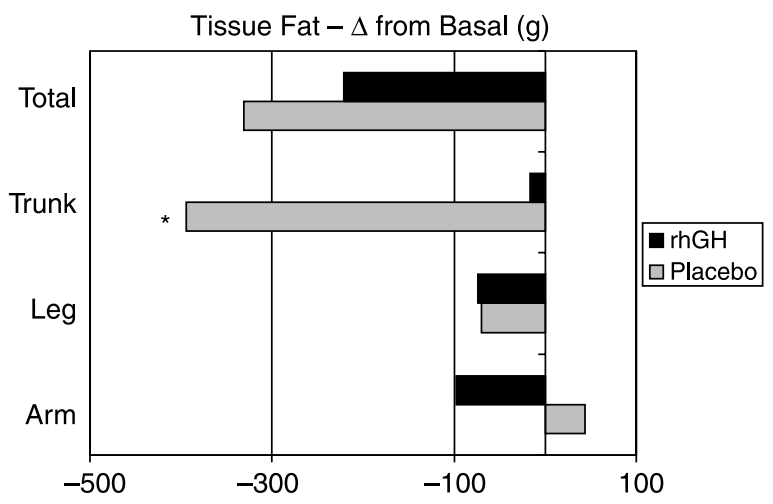

Figure 1 Variation of district tissue fat $(\mathrm{g})$ from the basal following rhGH or placebo. ${ }^{*} P=0.048$. 
an increment of muscle mass, or a detrimental effect on metabolic parameters. In detail: (i) the maximal stimulated GH peak after rhGH administration is comparable with the basal level; (ii) increased levels of plasma IGF-I in the treated group (rhGH administration vs placebo) confirmed the effectiveness of GH treatment with respect to the GH-IGF-I axis; and (iii) GH did not show any effect on glucose metabolism (data from OGTT) or on insulin sensitivity (data from HOMA IR). In contrast, there was evident a positive effect on lipid metabolism, with a modification of the pattern of plasma lipids, due to a decrease in total cholesterol and triglyceride levels. HAART was previously shown to modify the GH-IGF-I axis. For this reason we repeated the rhGH plus arginine stimulation tests at the beginning and at the end of each treatment/placebo period. Our data indicate that a 6 month period of rhGH treatment plus HAART does not modify the GHIGF-I axis.

The present results are relevant since a low-dose GH treatment improves body fat distribution and is devoid of metabolic side-effects. The question, which is still open, is the duration of the GH treatment effects. Previous work suggests the reversal of effects on fat distribution after cessation of $\mathrm{GH}$ treatment. For this reason, even in the light of the results of previous studies $(32-34)$, we foresee the possibility of proposing short periods of low-dose GH treatment ( 6 months as in the present work) combined with a program of physical training (to be performed continuously both during the treatment and the wash-out periods). In fact, physical exercise is known to be a powerful physiological stimulus for GH release in humans $(35,36)$ and can be utilized to perpetuate the effects of exogenously administered GH in patients with HIV lipodystrophy. Finally, the present results may also be relevant for future studies aimed at assessing the effect of lowdose $\mathrm{GH}$ treatment in clinical conditions (other than HIV lipodystrophy) characterized by visceral obesity. The known metabolic effects of higher doses of rhGH on glucose and lipid metabolism should always be taken into consideration $(37,38)$.

\section{Acknowledgements}

This study was sponsored by a grant from Pfizer (previously Pharmacia Upjohn).

\section{References}

1 Hirsch MS, Conway B, D'Aquila RT, Johnson VA, Brun-Vezinet F, Clotet B, Demeter LM, Hammer SM, Jacobsen DM, Kuritzkes DR, Loveday C, Mellors JW, Vella S \& Richman DD. Antiretroviral drug resistance testing in adults with HIV infection: implications for clinical management. International AIDS Society-USA Panel. Journal of the American Medical Association $1998 \mathbf{2 7 9}$ 1984-1991.

2 Carr A, Samaras K, Burton S, Law M, Freund J, Chisholm DJ \& Cooper DA. A syndrome of peripheral lipodystrophy, hyperlipidaemia and insulin resistance in patients receiving HIV protease inhibitors. AIDS 199812 51-58.

3 Carr A, Samaras K, Chisholm DJ \& Cooper DA. Pathogenesis of HIV-1-protease inhibitor-associated peripheral lipodystrophy, hyperlipidaemia, and insulin resistance. Lancet $1998 \mathbf{3 5 1}$ 1881-1883.

4 Bastard JP, Caron M, Vidal H, Jan V, Auclair M, Vigouroux C, Luboinski J, Laville M, Maachi M, Girard PM, Rozenbaum W, Levan P \& Capeau J. Association between altered expression of adipogenic factor SREBP1 in lipoatrophic adipose tissue from HIV-1-infected patients and abnormal adipocyte differentiation and insulin resistance. Lancet $20023591026-1031$.

5 Nolan D. Metabolic complications associated with HIV protease inhibitor therapy. Drugs $2003632555-2574$.

6 Brinkman K, Smeitink JA, Romijn JA \& Reiss P. Mitochondrial toxicity induced by nucleoside-analogue reverse-transcriptase inhibitors is a key factor in the pathogenesis of antiretroviral-therapyrelated lipodystrophy. Lancet $1999 \mathbf{3 5 4} 1112-1115$.

7 Badley DA, Roumier T, Lum JL \& Kroemer G. Mitochondrionmediated apoptosis in HIV-1 infection. Trends in Pharmacological Sciences $200324298-305$.

8 Renard E, Fabre J, Paris F, Reynes J \& Bringer J. Syndrome of body fat redistribution in HIV-1-infected patients: relationships to cortisol and catecholamines. Clinical Endocrinology $1999 \quad 51$ 223-230.

9 Rietschel P, Hadigan C, Corcoran C, Stanley T, Neubauer G, Gertner J \& Grinspoon S. Assessment of growth hormone dynamics in human immunodeficiency virus-related lipodystrophy. Journal of Clinical Endocrinology and Metabolism 200186 504-510.

10 Jorgensen JO, Krag M, Kanaley J, Moller J, Hansen TK, Moller N, Christiansen JS \& Orskov H. Exercise, hormones, and body temperature regulation and action of GH during exercise. Journal of Endocrinological Investigation 200326 838-842.

11 Murray RD, Adams JE \& Shalet SM. Adults with partial growth hormone deficiency have an adverse body composition. Journal of Clinical Endocrinology and Metabolism 200489 1586-1591.

12 Wahl PW, Savage PJ, Psaty BM, Orchard TJ, Robbins JA \& Tracy RP. Diabetes in older adults: comparison of 1997 American Diabetes Association classification of diabetes mellitus with 1985 WHO classification. Lancet 1998352 1012-1015.

13 Luzi L, Perseghin G, Tambussi G, Meneghini E, Scifo P, Pagliato E, Del Maschio A, Testolin G \& Lazzarin A. Intramyocellular lipid accumulation and reduced whole body lipid oxidation in HIV lipodystrophy. American Journal of Physiology. Endocrinology and Metabolism $2003 \mathbf{2 8 4} 274-280$.

14 Matthews DR, Hosker JP, Rudenski AS, Naylor BA, Treacher DF \& Turner RC. Homeostasis model assessment: insulin resistance and beta-cell function from fasting plasma glucose and insulin concentrations in man. Diabetologia 198528 412-419.

15 Ho KK, O'Sullivan AJ \& Hoffman DM. Metabolic action of growth hormone in man. Endocrine Journal 199643 57-63.

16 Cummings DE \& Merriam GR. Growth hormone therapy in adults. Annual Review of Medicine 200354 513-533.

17 Shi J, Sekhar RV, Balasubramanyam A, Ellis K, Reeds PJ, Jahoor D \& Sharma MD. Short-and long-term effects of growth hormone (GH replacement on protein metabolism in GH-deficient adults. Journal of Clinical Endocrinology and Metabolism $2003 \mathbf{8 8}$ 5827-5833.

18 Spina LD, Soares DV, Brasil RR, da Silva EM, Lobo PM, Conceicao FL \& Vaisman M. Glucose metabolism and visceral fat in GH deficient adults: one year of GH replacement. Growth Hormone and IGF Research 200414 45-51.

19 Langendonk JG, Meinders AE, Burgrraaf J, Frolich M, Roelen CA, Schoemaker RC, Cohen AF \& Pijl H. Influence of obesity and body fat distribution on growth hormone kinetics in humans. American Journal of Physiology. Endocrinology and Metabolism 1999277 $824-829$.

20 Vahl N, Jorgensen JOL, Skjaerbaek C, Veldhuis JD, Orskov H \& Christiansen JS. Abdominal adiposity rather than age and sex 
predicts mass and regularity of GH secretion in healthy adults. American Journal of Physiology. Endocrinology and Metabolism $19972721108-1116$.

21 Kim KR, Nam SY, Song YD, Lim SK, Lee HC \& Huh KB. Low-dose growth hormone treatment with diet restriction accelerate body fat loss, exerts anabolic effects and improves growth hormone secretory dysfunction in obese adults. Hormone Research 1999 $5178-84$.

22 Engelson ES, Glesby MJ, Mendez D, Albu JB, Wang J, Heymsfield GA \& Kotler DP. Effect of recombinant human growth hormone in the treatment of visceral fat accumulation in HIV infection. Journal of Acquired Immune Deficiency Syndrome $200230379-391$.

23 Lucidi P, Parlanti N, Piccioni F, Santeusanio F \& De Feo P. Shortterm treatment with low doses of recombinant human GH stimulates lipolysis in visceral obese men. Journal of Clinical Endocrinology and Metabolism 200287 3105-3109.

24 Weltman A, Despres JP, Clasey JL, Weltman JY, Wideman L, Kan J, Patrie J, Bergeron J, Thorner MO, Bouchard C \& Hartman ML. Impact of abdominal visceral fat, growth hormone, fitness, and insulin on lipids and lipoproteins in older adults. Metabolism $20035273-88$.

25 Martinez E, Mocroft A, Garcia-Viejo MA, Perez-Cuevas JB, Blanco JL, Mallolas J, Bianchi L, Conget I, Blanch J \& Phillips A. Risk of lipodystrophy in HIV-1 infected patients treated with protease inhibitors: a prospective cohort study. Lancet 2001357 $592-598$.

26 Viganò A, Mora S, Testolin C, Beccio S, Schneider L, Bricalli D, Vanzulli A, Manzoni P \& Brambilla P. Increased lipodystrophy is associated with increased exposure to highly active antiretroviral therapy in HIV-infected children. Journal of Acquired Immune Deficiency Syndrome 200332 482-489.

27 Viganò A, Mora S, Brambilla P, Schneider L, Merlo M, Monti LD \& Manzoni P. Impaired growth hormone secretion correlates with visceral adiposity in highly active antiretroviral treated HIVinfected adolescents. AIDS 200317 1435-1441.

28 Rietschel P, Hadigan C, Corcoran C, Stanley T, Neubauer G, Gertner J \& Grinspoon S. Assessment of growth hormone dynamics in human immunodeficiency virus-related lipodystrophy. Journal of Clinical Endocrinology and Metabolism 200186 504-510.

29 Hellerstein MK. Pathophysiology of body composition and metabolic abnormality in HIV-infection: therapeutic implications.
International Journal of Sport Nutrition and Exercise Metabolism 200111 105-110.

30 Tai VW, Schambelan M, Algren H, Shayevich C \& Mulligan K. Effects of recombinant human growth hormone on fat distribution in patients with human immunodeficiency virus associated wasting. Clinical Infectious Diseases 200235 1258-1262.

31 Engelson ES. HIV lipodystrophy diagnosis and management. Body composition and metabolic alterations: diagnosis and management. AIDS Reader 200313 10-14.

32 Kotler DP, Muurahainen N, Grunfeld C, Wanke C, Thompson M, Saag M, Bock D, Simons G \& Gertner JM. Serostim in Adipose Redistribution Syndrome Study Group. Effects of growth hormone on abnormal visceral adipose tissue accumulation and dyslipidemia in HIV-infected patients. Journal of Acquired Immune Deficiency Syndrome. $200435239-252$.

33 Benavides S \& Nahata MC. Pharmacologic therapy for HIV-associated lipodystrophy. Annals of Pharmacotherapy 200438 448-457.

34 Driscoll SD, Meininger GE, Lareau MT, Dolan SE, Killilea KM, Hadigan CM, Lloyd-Jones DM, Klibanski A, Frontera WR \& Grinspoon SK. Effects of exercise training and metformin on body composition and cardiovascular indices in HIV-infected patients. AIDS $2004 \mathbf{1 8} 465-473$.

35 Jorgensen JO, Krag M, Kanaley J, Moller J, Hansen TK, Moller N, Christiansen JS \& Orskov H. Exercise, hormones, and body temperature. Regulation and action of GH during exercise. Journal of Endocrinological Investigation 20039 838-842.

36 Thomas SG, Esposito JG \& Ezzat S. Exercise training benefits growth hormone (GH deficient adults in the absence or presence of GH treatment. Journal of Clinical Endocrinology and Metabolism $2003885737-5738$.

37 Jorgensen JO, Krag M, Jessen N, Norrelund H, Vestergaard ET, Moller N \& Christiansen JS. Growth hormone and glucose homeostasis. Hormone Research 200461 607-611.

38 Boguszewski CL, Meister LH, Zaminelli DC \& Radominski RB. One year of GH replacement therapy with a fixed low-dose regimen improves body composition, bone mineral density and lipid profile of GH-deficient adults. European Journal of Endocrinology 2005 $15267-75$

Received 28 June 2005

Accepted 1 September 2005 